\title{
ASSOCIATION BETWEEN SMOKING, CRACK COCAINE ABUSE AND THE DISCONTINUATION OF COMBINATION ANTIRETROVIRAL THERAPY IN RECIFE, PERNAMBUCO, BRAZIL
}

\author{
Joanna d'Arc Lyra BATISTA(1), Maria de Fátima Pessoa Militão de ALBUQUERQUE(2), Marcela Lopes SANTOS(2), Demócrito de Barros MIRANDA-FILHO(3), \\ Heloísa Ramos LACERDA(1,3), Magda MARUZA(4), Libia Vilela MOURA(1), Isabella COIMBRA(3) \& Ricardo Arraes de Alencar XIMENES(1,3)
}

\begin{abstract}
SUMMARY
Despite the effectiveness of combination antiretroviral therapy in the treatment of people living with HIV/AIDS (PLWHA), nonadherence to medication has become a major threat to its effectiveness. This study aimed to estimate the prevalence of self-reported irregular use of antiretroviral therapy and the factors associated with such an irregularity in PLWHA. A cross-sectional study of PLWHA who attended two referral centers in the city of Recife, in Northeastern Brazil, between June 2007 and October 2009 was carried out. The study analyzed socioeconomic factors, social service support and personal habits associated with nonadherence to antiretroviral therapy, adjusted by multivariable logistic regression analysis. The prevalence of PLWHA who reported irregular use of combination antiretroviral therapy (cART) was $25.7 \%$. In the final multivariate model, the irregular use of cART was associated with the following variables: being aged less than 40 years $(\mathrm{OR}=1.66,95 \%$-CI: $1.29-2.13)$, current smokers $(\mathrm{OR}=1.76,95 \%$-CI: $1.31-2.37)$ or former smokers $(\mathrm{OR}=1.43,95 \%$-CI: $1.05-1.95)$, and crack cocaine users $(\mathrm{OR}=2.79,95 \%$-CI: $1.24-6.32)$. Special measures should be directed towards each of the following groups: individuals aged less than 40 years, smokers, former smokers and crack cocaine users. Measures for giving up smoking and crack cocaine should be incorporated into HIV-control programs in order to promote greater adherence to antiretroviral drugs and thus improve the quality of life and prolong life expectancy.
\end{abstract}

KEYWORDS: AIDS; Adherence; Antiretroviral therapy; Associated factors.

\section{INTRODUCTION}

Although the number of new HIV infections has declined globally by $19 \%$ over the past decade and the access to antiretroviral therapy in low- and middle-income countries has increased, HIV infection rates are increasing in several countries in Eastern Europe and central Asia, notably among injecting drug users and their sexual networks ${ }^{29}$. Access to antiretroviral treatment (ART) has been primarily responsible for prolonging and improving the lives of people living with HIV/AIDS (PLWHA), with Brazil, being the first developing country to implement the universal distribution of these drugs ${ }^{8,18}$. Consequently, nonadherence to the use of antiretroviral drugs is the greatest risk for a non-effective response to treatment and the possibility of spreading resistant viruses ${ }^{25,27}$. Moreover, poor adherence is one of the factors that may lead to a lower CD4 cell count, higher plasma viral RNA levels and delayed immune recovery, with progression of the disease that can lead to death ${ }^{11}$.

In the treatment of chronic disease, the degree of adherence is always influenced by a number of different factors: characteristics of the individual, characteristics of the disease, social support network (family and friends) and factors related to the health service, such as difficulties in accessing it, and the relationship of the health team/individual ${ }^{12}$. Amongst the characteristics of the individual, habits such as alcoholism, drug abuse and irregular use of antiretrovirals ${ }^{21}$ place the individual at further risk of secondary infections. Furthermore, studies have shown that the quantity of pills is also an important factor that influences the rate of adherence ${ }^{8,11}$.

For the treatment of HIV infection to be effective, several authors recommend an adherence level of at least $95 \%$ of the prescribed drugs to decrease the chance of viral resistance ${ }^{6}$. However, recent studies indicate that for boosted protease inhibitors an adherence level greater than $80 \%$ would be equally effective ${ }^{16}$.

Different methods have been employed in order to measure adherence to antiretrovirals, without a consensus gold standard. Due to their simplicity and the low costs involved, methods that use self-reports are widely used, and studies have demonstrated an association between the measure of self-reported adherence to antiretrovirals and HIV plasma viral load (with odds ratios and hazard ratios on the order of 2.0), making it possible to use this strategy in the conduct of PLWHA ${ }^{26,30}$.

The aim of this study was to identify the prevalence of the factors

(1) Universidade Federal de Pernambuco, Recife, Pernambuco, Brazil.

(2) Centro de Pesquisas Aggeu Magalhães/FIOCRUZ, Recife, Pernambuco, Brazil

(3) Universidade de Pernambuco, Recife, Pernambuco, Brazil.

(4) Hospital Correia Picanço, Secretaria de Saúde, Recife, Pernambuco, Brazil

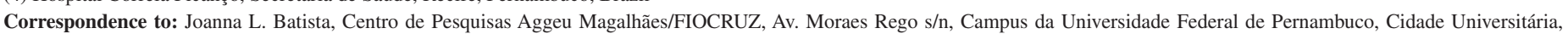
50670-420 Recife, Pernambuco, Brasil. Fax: 5581 2101-2614. E-mail joannalyra@gmail.com.br 


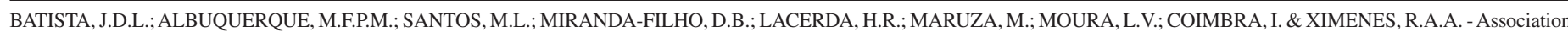
between smoking crack cocaine abuse and the discontinuation of combination antiretroviral therapy in Recife, Pernambuco, Brazil. Rev. Inst. Med. Trop. Sao Paulo, 56(2): 127-32, 2014.

associated with the irregular use of antiretroviral drugs in people living with HIV, with special emphasis on socioeconomic factors and life habits, intending thereby to identify the groups at greatest risk so as to develop new strategies that set out to minimize the problem.

\section{METHODS}

The study was conducted in Recife, a city in northeastern Brazil, with an estimated population of 1,561,659 inhabitants. This cross-sectional study was carried out in June 2007 and October 2009, with people living with HIV/AIDS aged 18 years and over, who attended two HIV referral centers in the state of Pernambuco (Hospital Correia Picanço and Hospital Universitário Oswaldo Cruz), which attend around $60 \%$ of the state's patients. Individuals were invited to participate in the study either during routine consultations and/or hospitalization. Those who agreed to take part gave informed consent and were then interviewed by trained professionals who used a questionnaire developed specifically for this study. Hospitalized patients who could not answer the questionnaire due to their clinical condition were excluded from the study.

The dependent variable was the self-reported irregular use of combined antiretroviral therapy (cART), categorized in 'yes' - when patients reported a discontinuation of treatment at some point on their own - and 'no'.

The independent variables were classified as: demographic (age and race), socioeconomics (marital status, social service support, head of household's income), how long the patient has been aware of being HIV positive, life habits (alcoholism and drug abuse). Information regarding the use of cART was collected from medical records.

Users of illicit drugs (crack cocaine and cocaine) fell into the following categories: non-users; intermittent (intermittent users who had abstained during the past year) and current users (who had been using during the past year).

The criteria adopted for alcohol consumption was based on the number of drinks per day, according to the definition of alcohol consumption patterns approved by the Centers for Disease Control and Prevention $(\mathrm{CDC})^{7}$. Patients were questioned about their alcohol consumption in the previous three months. Patients were classified as abstainers or light drinkers (non-drinkers or less than two drinks per day for men and one drink for women), and heavy drinkers (more than two drinks per day for men and more than one drink per day for women).

The Student's t-test was used to compare the mean scores of the independent samples and variance was tested with Levene's test. All variables associated with the irregular use of cART in the univariate analysis with a $p$-value of less than 0.20 were included in the multivariate analysis, using logistic regression and Odds Ratio (OR) with a confidence interval of $95 \%$. The variables whose association with the event was statistically significant $(p<0.05)$ remained in the final multivariate model. The software used was Stata 11.2 (StataCorp LP, College Station, TX). The study is part of a cohort, which has been carried out in two research centers, and was approved by the Ethics and Research Committee of the Centro de Ciências da Saúde da Universidade Federal de Pernambuco.

\section{RESULTS}

In the period from June 2007 to October 2009, 1815 PLWHA were interviewed, of which 1432 (78.9\%) were taking cART. Of these, 52 (3.6\%) did not answer the question referring to the irregular use of treatment, and were therefore excluded from the study. The study sample was made up of 1380 patients with a mean age of 40.6 years (18-80) and a median age of 40.0 years; $64.1 \%$ were male and $79.1 \%$ had monthly family income of less than two minimum wages. The majority (84.7\%) lived in the metropolitan region of Recife. The prevalence of people who reported irregular use of cART was $25.7 \%$. Among people who reported irregular use of cART, $42 \%$ had stopped taking the pills in the two weeks preceding the study interview.

A comparison of the mean ages, CD4 cell count and HIV viral load at the time of the interview revealed an association between self-reported irregular use of cART, being under 40 years old and a lower CD4 cell count (Table 1).

Table 1 shows the frequency distribution of the studied factors and the

Table 1

Frequencies and univariate analysis of the association between characteristics of people living with HIV/AIDS and the irregular use of antiretroviral treatment, Recife, Pernambuco, Brazil, 2009

\begin{tabular}{|c|c|c|c|c|c|c|}
\hline & \multicolumn{2}{|c|}{ Irregular use of ART (case) } & \multicolumn{2}{|c|}{ Regular use of ART (control) } & \multirow[t]{2}{*}{ Crude OR (CI) } & \multirow[t]{2}{*}{$p$} \\
\hline & $\mathrm{n}$ & $\%$ & $\mathrm{n}$ & $\%$ & & \\
\hline \multicolumn{7}{|l|}{ Age } \\
\hline Years (mean) & 38.8 & & 41.3 & & & $0.001 *$ \\
\hline \multicolumn{7}{|l|}{ Age } \\
\hline$\geq 40$ years & 157 & 21.39 & 577 & 78.61 & 1.0 & \\
\hline$<40$ years & 198 & 30.65 & 448 & 69.35 & $1.62(1.27-2.07)$ & 0.000 \\
\hline Total & 355 & 25.72 & 1025 & 74.28 & & \\
\hline \multicolumn{7}{|l|}{ Sex } \\
\hline Female & 138 & 27.88 & 357 & 72.12 & 1.0 & \\
\hline Male & 217 & 24.52 & 668 & 75.48 & $0.84(0.65-1.08)$ & 0.171 \\
\hline Total & 355 & 25.72 & 1025 & 74.28 & & \\
\hline
\end{tabular}


Table 1 (continuation)

\begin{tabular}{|c|c|c|c|c|c|c|}
\hline & \multicolumn{2}{|c|}{ Irregular use of ART (case) } & \multicolumn{2}{|c|}{ Regular use of ART (control) } & \multirow[t]{2}{*}{ Crude OR (CI) } & \multirow[t]{2}{*}{$p$} \\
\hline & $\mathrm{n}$ & $\%$ & $\mathrm{n}$ & $\%$ & & \\
\hline \multicolumn{7}{|l|}{ Skin color } \\
\hline White & 92 & 25.34 & 271 & 74.66 & 1.0 & \\
\hline Non-white & 263 & 25.86 & 754 & 74.14 & $1.03(0.78-1.35)$ & 0.847 \\
\hline Total & 355 & 25.72 & 1025 & 74.28 & & \\
\hline \multicolumn{7}{|l|}{ Alcohol intake } \\
\hline Heavy drinker & 225 & 23.61 & 728 & 76.39 & 1.0 & \\
\hline Light drinker or abstainer & 130 & 30.44 & 297 & 69.56 & $1.42(1.10-1.83)$ & 0.007 \\
\hline Total & 355 & 25.72 & 1025 & 74.28 & & \\
\hline \multicolumn{7}{|l|}{ Smoking status } \\
\hline Never smoked & 133 & 21.28 & 492 & 78.72 & 1.0 & \\
\hline Former smoker & 97 & 26.08 & 275 & 73.92 & $1.30(0.97-1.76)$ & 0.083 \\
\hline Current smoker & 125 & 32.64 & 258 & 67.36 & $1.79(1.34-2.39)$ & 0.000 \\
\hline Total & 355 & 25.72 & 1025 & 74.28 & & \\
\hline \multicolumn{7}{|l|}{ Use of cocaine } \\
\hline Never used & 311 & 25.04 & 931 & 74.96 & 1.0 & \\
\hline Intermittent users** & 37 & 29.84 & 87 & 70.16 & $1.27(0.85-1.91)$ & 0.243 \\
\hline Current users & 7 & 58.33 & 5 & 41.67 & $4.19(1.32-13.3)$ & 0.015 \\
\hline Total & 355 & 25.76 & 1023 & 74.24 & & \\
\hline \multicolumn{7}{|l|}{ Use of crack } \\
\hline Never used & 319 & 24.79 & 968 & 75.21 & 1.0 & \\
\hline Intermittent users** & 22 & 32.84 & 45 & 67.16 & $1.48(0.88-2.51)$ & 0.141 \\
\hline Current users & 14 & 56.00 & 11 & 44.00 & $3.86(1.73-8.59)$ & 0.001 \\
\hline Total & 355 & 25.74 & 1024 & 74.26 & & \\
\hline \multicolumn{7}{|l|}{ Can read and write } \\
\hline Yes & 317 & 26.05 & 900 & 73.95 & 1.0 & \\
\hline No & 37 & 24.03 & 117 & 75.97 & $0.90(0.61-1.33)$ & 0.589 \\
\hline Total & 354 & 25.82 & 1017 & 74.18 & & \\
\hline \multicolumn{7}{|l|}{ Monthly income of head of family } \\
\hline$\geq 2$ minimum wages & 55 & 22.36 & 191 & 77.64 & 1.0 & \\
\hline$<2$ minimum wages & 251 & 26.96 & 680 & 73.04 & $1.28(0.92-1.79)$ & 0.144 \\
\hline Total & 306 & 26.00 & 871 & 74.00 & & \\
\hline \multicolumn{7}{|l|}{ Marital status } \\
\hline Married & 64 & 22.38 & 222 & 77.62 & 1.0 & \\
\hline Other*** & 291 & 26.60 & 803 & 73.40 & $1.26(0.92-1.71)$ & 0.146 \\
\hline Total & 355 & 25.72 & 1025 & 74.28 & & \\
\hline \multicolumn{7}{|l|}{ Social service support } \\
\hline Lives with family or partner & 282 & 25.59 & 820 & 74.41 & 1.0 & \\
\hline Lives alone or in a shelter & 73 & 26.26 & 205 & 73.74 & $1.03(0.77-1.39)$ & 0.820 \\
\hline Total & 355 & 25.72 & 1025 & 74.28 & & \\
\hline \multicolumn{7}{|l|}{ City of residence } \\
\hline Recife & 148 & 26.86 & 403 & 73.14 & 1.0 & \\
\hline Other & 204 & 24.97 & 613 & 75.03 & $0.91(0.71-1.16)$ & 0.433 \\
\hline Total & 352 & 25.73 & 1016 & 74.27 & & \\
\hline \multicolumn{7}{|l|}{ CD4 baseline } \\
\hline cells $/ \mathrm{mm}^{3}($ mean $)$ & 383.9 & & 446.1 & & & $0.002 *$ \\
\hline \multicolumn{7}{|l|}{ Viral load baseline } \\
\hline copies/mL (mean) & $29,501.7$ & & $18,114.7$ & & & 0.198* \\
\hline
\end{tabular}




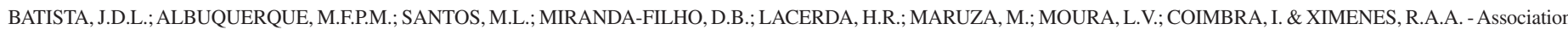
between smoking crack cocaine abuse and the discontinuation of combination antiretroviral therapy in Recife, Pernambuco, Brazil. Rev. Inst. Med. Trop. Sao Paulo, 56(2): 127-32, 2014.

Table 2

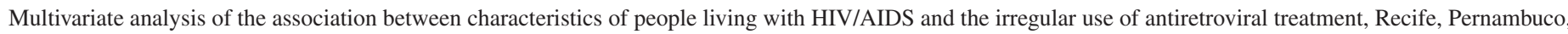
Brazil, 2009

\begin{tabular}{|c|c|c|c|c|}
\hline & \multicolumn{2}{|c|}{ Crude OR } & \multicolumn{2}{|c|}{ OR adjusted by the multivariate } \\
\hline & $\mathrm{OR}(\mathrm{CI})$ & $p$ & $\mathrm{OR}(\mathrm{CI})$ & $p$ \\
\hline \multicolumn{5}{|l|}{ Age } \\
\hline$\geq 40$ years & 1.0 & & 1.0 & \\
\hline$<40$ years & $1.62(1.27-2.07)$ & 0.000 & $1.66(1.29-2.13)$ & 0.000 \\
\hline \multicolumn{5}{|l|}{ Smoking } \\
\hline Never smoked & 1.0 & & 1.0 & \\
\hline Former smoker & $1.30(0.97-1.76)$ & 0.083 & $1.43(1.05-1.95)$ & 0.023 \\
\hline Current smoker & $1.79(1.34-2.39)$ & 0.000 & $1.76(1.31-2.37)$ & 0.000 \\
\hline \multicolumn{5}{|l|}{ Use of crack } \\
\hline Never used & 1.0 & & 1.0 & \\
\hline Intermittent users* & $1.48(0.88-2.51)$ & 0.141 & $1.20(0.70-2.06)$ & 0.501 \\
\hline Current users & $3.86(1.73-8.59)$ & 0.001 & $2.79(1.24-6.32)$ & 0.013 \\
\hline
\end{tabular}

* Users who have abstained during the past year.

result of the univariate analysis of the association with the self-reported irregular use of cART.

Regarding the habits of the study population (Table 1 ), $69.1 \%$ were considered abstainers or light drinkers of alcoholic beverages; most participants had never used cocaine or crack cocaine $(90.1 \%$ and $93.3 \%$ respectively); in relation to smoking, most individuals $(54.7 \%)$ were current or former smokers, the majority $(84.2 \%)$ having consumed cigarettes for 10 years or more.

In the multivariate analysis (Table 2), associations with the irregular use of cART in a statistically significant manner were, an age lower than or equal to $39(p<0.001)$, a former smoker $(p=0.023)$, currently smoking $(p<0.001)$ and currently using crack cocaine $(p=0.013)$.

\section{DISCUSSION}

After adjusting the socioeconomic and social service support variables, the discontinuation of combination antiretroviral therapy was associated with the following variables: being aged less than 40 years, a former smoker or a current smoker and a crack cocaine user.

The prevalence of people who reported irregular use of cART was $25.7 \%$. This prevalence was similar to the prevalence of non-adherence to treatment encountered in a number of studies in Brazil $1^{4,6,23,25}$. Most studies conclude that taking less than $90-95 \%$ of prescription drugs is an indication of non-adherence, unlike the present study, which evaluated individual patient responses to questions regarding the discontinuation of treatment at some point in time. Studies also show the importance of including additional resources to self-reporting, such as testing tablets, to provide a better evaluation of adherence ${ }^{22}$. Even without a consensus concerning the method of measuring this adherence, studies have indicated similar results of prevalence, demonstrating that the most appropriate method of certifying adherence to treatment was to question the patient directly. The strategy which uses, direct patient questioning, was chosen because it is easy to employ in everyday health care. We are aware that adherence may be overestimated due to a fear of displeasing the interviewer, the health professional or physician (false negative response); however those who actually report poor adherence are probably expressing the truth (decrease in false positive response) and are an important group to intervene with. The option for the question on abandonment of treatment at some point, without the restriction to a length time before and after the interview, aimed to expand the knowledge of the problem. We recognize that in the systematic care to the patient, the definition of a time span would be crucial in the evaluation of the patient's response to treatment and in the selection of the best intervention to be adopted to change the patient's behavior. It would also minimize recall bias.

Most of the patients from this study were male and had a low monthly family income. These factors were related to poor adherence to antiretroviral treatment in another study ${ }^{12}$. Low socioeconomic status may be a proxy of several factors associated to nonadherence, such as difficulties in accessing the health system, difficulties involved in understanding the individual regarding his/her health situation, etc. ${ }^{26}$. Since the research involved a very low socioeconomic population, the study of the association of characteristics such as lifestyle, with the irregular use of cART, may be more specific to define the individual at risk.

Research has indicated that older patients have a better adherence to antiretroviral treatment ${ }^{15}$, which also reinforces the findings of this study. It is possible that, due to a better perception of their own health, older people tend to better assimilate the importance of treatment and the consequences of interrupting it. This data was also encountered in another study undertaken in Brazil, where being younger was related to low adherence to the treatment ${ }^{5}$.

Being a former smoker or a current smoker was associated with the discontinuation of combination antiretroviral therapy. Cigarette smoking has been associated with sexual behavior and drug abuse $\mathrm{e}^{1,13}$ and with a lower inclination to develop healthy behaviors related to 


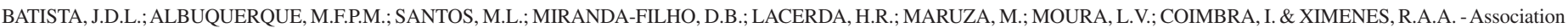
between smoking crack cocaine abuse and the discontinuation of combination antiretroviral therapy in Recife, Pernambuco, Brazil. Rev. Inst. Med. Trop. Sao Paulo, 56(2): 127-32, 2014.

$\operatorname{diet}^{17,20}$ and physical activity ${ }^{17}$. The same mechanism that predisposes all these behaviors may also lie behind, associated or not with these factors, a behavior less prone to adhere to medication. A study carried out by our group, in a cohort of people living with HIV/AIDS and under tuberculosis treatment, showed an association between smoking and the evasion of tuberculosis treatment ${ }^{19}$. The present study corroborates the findings of other authors who found an association between smoking and lower adherence to antiretrovirals ${ }^{4,24}$, either smoking alone or as part of a risky behavior profile. Depression has been thought of as a possible mediator between smoking and adherence to antiretrovirals ${ }^{28}$ but this is not a finding common to all authors ${ }^{4}$.

People who use drugs tend to be more socially vulnerable and have a chaotic, unstable lifestyle that influences the adherence to any type of chronic treatment ${ }^{8}$. The use of illicit drugs has been associated with both nonadherence and a decrease in the viral and immunologic responses to antiretrovirals ${ }^{18}$, the former also being a finding in the present study. Research has demonstrated that cocaine (including the crack variation) has an influence over the pathogenesis of AIDS, accelerating its progression and the risk of mortality, morbidity and an increased viral load $^{9,10}$. For this group, an increase in the viral load may be related to nonadherence to the treatment, which may lead to viral resistance and subsequently to an immunological decline, thus favoring the HIV virus and its replication.

Studies show that direct administered antiretroviral therapy (DAART) in people living with HIV/AIDS who use drugs may improve adherence and thus improve the immune status of the individual ${ }^{2,3}$. Beyond DAART, other interventions such as counseling by motivational interviewing or video information, which is feasible in health care centers, improve adherence to antiretroviral treatment and maintain their efficacy three months later ${ }^{14}$.

Once adherence to treatment has been promoted through individual approaches and discussions by health professionals in the majority of the specialized services for treating PLWHA, differentiated attention towards smokers and crack users, as well as interaction with specific control programs, are central to good adherence to antiretroviral treatment and the consequent reduction of viral resistance.

This study has some constraints. We are aware that the strategy used to measure the use of illicit substances may not be very accurate as a participant who has experienced crack cocaine once in the previous 12 months, an occasional user and a drug dependent (who used crack cocaine in the same time span), are all classified as current users of crack cocaine, although usage patterns and possibly behavior differ. The constraint posed to the interpretation of our findings by the discontinuation of combination antiretroviral therapy being measured has already been mentioned. Finally, a major limitation of this study, because of its cross-sectional design, is that it is not possible to establish the temporal sequence between exposure and outcome and differentiate cause and effect. Nevertheless the results pointed to groups which should be monitored differentially because of their association with discontinuation of combination antiretroviral therapy.

Further studies, using a longitudinal design and more restricted definitions, could complement our findings.

\section{RESUMO}

\section{Associação entre tabagismo e o uso de crack com a descontinuidade da terapia antirretroviral combinada em Recife, Pernambuco, Brasil}

Apesar da eficácia da terapêutica antirretroviral combinada para o tratamento de pessoas vivendo com HIV/Aids, a não adesão aos medicamentos tem se tornado uma das maiores ameaças à efetividade dessa terapêutica. O objetivo desse estudo foi estimar a prevalência de uso irregular autorreferido da terapia antirretroviral e os fatores associados com essa irregularidade em pessoas vivendo com HIV. Foi realizado um estudo seccional de pessoas vivendo com HIV/Aids atendidas em dois centros de referência no Recife, Nordeste do Brasil, entre junho 2007 e outubro de 2009. Foram analisados os fatores socioeconômicos, de apoio social e de hábitos do indivíduo, ajustados através de análise de regressão logística multivariada. A prevalência de pessoas vivendo com HIV/Aids que relataram o uso irregular da terapia antirretroviral combinada (TARC) foi de $25,7 \%$. No modelo multivariado final, o uso irregular da TARC esteve associado às seguintes variáveis: ter menos de 40 anos (OR = 1,66, IC95\%: 1,29-2,13), fumantes (OR = 1,76, IC95\%: 1,31-2,37) ou ex-fumantes ( $\mathrm{OR}=1,43$, IC95\%: 1,05-1,95) e ser usuário de crack $(\mathrm{OR}=2,79$, IC95\%: 1,24-6,32). Medidas especiais devem ser direcionadas para cada um dos seguintes grupos: adultos com menos de 40 anos, fumantes, ex-fumantes e usuários de crack. Ações voltadas para a cessação do tabagismo e do crack devem ser incorporadas ao programa de controle dos infectados pelo HIV, visando promover a maior adesão aos antirretrovirais e, consequentemente, aumentar a expectativa e a qualidade de vida.

\section{COMPETING INTERESTS}

The authors declared that there are no competing interests.

\section{FUNDING}

Ministério da Saúde/Programa DST/AIDS/UNESCO (CSV 182/06 - Projeto "Estudo Clínico-Epidemiológico da co-infecção HIV/ Tuberculose em Recife"). The authors received partial support from the Conselho Nacional de Desenvolvimento Científico e Tecnológico - CNPq (scholarship 150425/2012-0 to J.D.L.B., 300917/2006-6 to R.A.A.X. and 301779/2009-0 to M.F.P.M.).

\section{REFERENCES}

1. Anteghini M, Fonseca H, Ireland M, Blum R. Health risk behaviors and associated risk and protective factors among Brazilian adolescents in Santos, Brazil. J Adolesc Health. 2001;28:295-302.

2. Babudieri S, Dorrucci M, Boschini A, Carbonara S, Longo B, Monarca R, et al. Targeting candidates for directly administered highly active antiretroviral therapy: benefits observed in HIV-infected injecting drug users in residential drugrehabilitation facilities. AIDS Patient Care STDS. 2011;25:359-64.

3. Berg KM, Litwin A, Li X, Heo M, Arnsten JH. Directly observed antiretroviral maintenance clinics: a randomized controlled trial. Drug Alcohol Depend. 2011;113:192-9.

4. Bonolo PF, Machado CJ, Cesar CC, Ceccato MG, Guimaraes MD. Vulnerability and non-adherence to antiretroviral therapy among HIV patients, Minas Gerais State, Brazil. Cad Saude Publica. 2008;24:2603-13. 


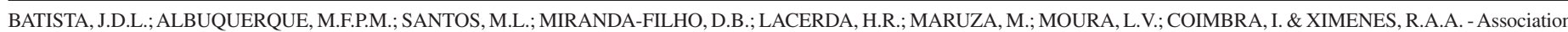
between smoking crack cocaine abuse and the discontinuation of combination antiretroviral therapy in Recife, Pernambuco, Brazil. Rev. Inst. Med. Trop. Sao Paulo, 56(2): 127-32, 2014.

5. Carvalho CV, Duarte DB, Merchán-Hamann E, Bicudo E, Laguardia J. Determinantes da aderência à terapia anti-retroviral combinada em Brasília, Distrito Federal, Brasil, 1999-2000. Cad Saude Publica. 2003;19:593-604.

6. Carvalho CV, Merchán-Hamann E, Matsushita R. Determinantes da adesão ao tratamento anti-retroviral em Brasília, DF: um estudo de caso-controle. Rev Soc Bras Med Trop. 2007;40:555-65

7. Centers for Disease Control and Prevention. Fact sheets in alcohol and public health. [cited 2011 October 7]. Available from: http://www.cdc.gov/alcohol/fact-sheets/ binge-drinking.htm

8. Colombrini MR, Lopes MHBM, de Figueiredo RM. Adesão à terapia antiretroviral para HIV/AIDS. Rev Esc Enferm USP. 2006;40:576-81.

9. Cook JA. Associations between use of crack cocaine and HIV-1 disease progression: research findings and implications for mother-to-infant transmission. Life Sci. 2011;88(21-22):931-9.

10. Cook JA, Burke-Miller JK, Cohen MH, Cook RL, Vlahov D, Wilson TE, et al. Crack cocaine, disease progression, and mortality in a multicenter cohort of HIV-1 positive women. AIDS. 2008;22:1355-63.

11. Do NT, Phiri K, Bussmann H, Gaolathe T, Marlink RG, Wester CW. Psychosocial factors affecting medication adherence among HIV-1 infected adults receiving combination antiretroviral therapy (cART) in Botswana. AIDS Res Hum Retroviruses. 2010;26:685-91.

12. Gir E, Vaichulonis CG, Oliveira MD. Adesão à terapêutica anti-retroviral por indivíduos com HIV/AIDS assistidos em uma instituição do interior paulista. Rev Lat Am Enfermagem. 2005;13:634-41.

13. Hershberger SL, Fisher DG, Reynolds GL, Klahn JA, Wood MM. Nicotine dependence and HIV risk behaviors among illicit drug users. Addict Behav. 2004;29:623-5.

14. Ingersoll KS, Farrell-Carnahan L, Cohen-Filipic J, Heckman CJ, Ceperich SD, Hettema $\mathrm{J}$, et al. A pilot randomized clinical trial of two medication adherence and drug use interventions for HIV+ crack cocaine users. Drug Alcohol Depend. 2011;116:177-87.

15. Kastrissios H, Suarez JR, Katzenstein D, Girard P, Sheiner LB, Blaschke TF. Characterizing patterns of drug-taking behavior with a multiple drug regimen in an AIDS clinical trial. AIDS. 1998;12:2295-303

16. Kobin $\mathrm{AB}$, Sheth NU. Levels of adherence required for virologic suppression among newer antiretroviral medications. Ann Pharmacother. 2011:45:372-9.

17. Fine LJ, Philogene GS, Gramling R, Coups EJ, Sinha S. Prevalence of multiple chronic disease risk factors: 2001 National Health Interview Survey. Am J Prev Med. 2004;27(2 Suppl):18-24

18. Lucas GM, Cheever LW, Chaisson RE, Moore RD. Detrimental effects of continued illicit drug use on the treatment of HIV-1 infection. J Acquir Immune Defic Synd. $2001 ; 27: 251-9$
19. Maruza M, Albuquerque MFPM, Coimbra I, Moura LV, Montarroyos UR, MirandaFilho DB, et al. Risk factors for default from tuberculosis treatment in HIV-infected individuals in the state of Pernambuco, Brazil: a prospective cohort study. BMC Infect Dis. 2011;11:351.

20. Morabia A, Curtin F, Bernstein MS. Effects of smoking and smoking cessation on dietary habits of a Swiss urban population. Eur J Clin Nutr. 1999;53:239-43.

21. Pence BW, Thielman NM, Whetten K, Ostermann J, Kumar V, Mugavero MJ. Coping strategies and patterns of alcohol and drug use among HIV-infected patients in the United States Southeast. AIDS Patient Care STDS. 2008;22:869-77.

22. Polejack L, Seidl EMF. Monitoramento e avaliação da adesão ao tratamento antirretroviral para HIV/aids: desafios e possibilidades. Cien Saude Colet. 2010;15(Suppl 1):1201-8.

23. Seidl EMF, Melchíades A, Farias V, Brito A. Pessoas vivendo com HIV/AIDS: variáveis associadas à adesão ao tratamento anti-retroviral. Cad Saude Publica. 2007;23:2305-16.

24. Shuter J, Bernstein SL. Cigarette smoking is an independent predictor of nonadherence in HIV-infected individuals receiving highly active antiretroviral therapy. Nicotine Tob Res. 2008;10:731-6.

25. Silva MC, Ximenes RA, Miranda Filho DB, Arraes LW, Mendes M, Melo AC, $a l$. Risk-factors for non-adherence to antiretroviral therapy. Rev Inst Med Trop Sao Paulo. 2009;51:135-9.

26. Simoni JM, Kurth AE, Pearson CR, Pantalone DW, Merrill JO, Frick PA. Self-repor measures of antiretroviral therapy adherence: a review with recommendations for HIV research and clinical management. AIDS Behav. 2006;10:227-45

27. Venkatesh KK, Srikrishnan AK, Mayer KH, Kumarasamy N, Raminani S, Thamburaj E, et al. Predictors of nonadherence to highly active antiretroviral therapy among HIV-infected South Indians in clinical care: implications for developing adherence interventions in resource-limited settings. AIDS Patient Care STDS. 2010;24:795-803.

28. Webb MS, Vanable PA, Carey MP, Blair DC. Medication adherence in HIVinfected smokers: the mediating role of depressive symptoms. AIDS Educ Prev. 2009;21(3 Suppl):94-105

29. World Health Organization. Global health sector strategy on HIV/AIDS 2011-2015 Geneva: WHO; 2011

30. Wilson IB, Carter AE, Berg KM. Improving the self-report of HIV antiretroviral medication adherence: is the glass half full or half empty? Curr HIV/AIDS Rep. 2009;6:177-86.

Received: 14 August 2012

Accepted: 5 August 2013 